Article

\title{
The Water Footprint Assessment of Electricity Production: An Overview of the Economic-Water-Energy Nexus in Italy
}

\author{
Pier Paolo Miglietta ${ }^{1, *}$, Domenico Morrone ${ }^{2}$ and Federica De Leo ${ }^{1}$ \\ 1 Department of Economics and Management, University of Salento, Via per Monteroni, 73100 Lecce, Italy; \\ federica.deleo@unisalento.it \\ 2 Department of Management, LUM University, S.S. 100 km 18, 70010 Casamassima, Italy; morrone@lum.it \\ * Correspondence: pierpaolo.miglietta@unisalento.it; Tel.: +39-0832-298-628
}

Received: 13 December 2017; Accepted: 12 January 2018; Published: 17 January 2018

\begin{abstract}
The term "water-energy nexus" has remarkable implications in the sustainable management of water resources. The aim of this paper is to analyse the production of electricity, from an economic and technical perspective, using the water footprint and economic water productivity approaches. After comparing the percentage of contribution of fossil and renewable sources to the production of the electricity sector, the study then compares the percentage of contribution of fossil and renewable sources to the consumptive water footprint of Italian electricity production for each year analysed. Furthermore, distinguishing between renewable and fossil sources, the paper proceeds to assess the total consumptive water footprint generated by each energy source for the electricity production in Italy during the period 2007-2016. The study represents an original contribution for the identification of policies and managerial implications in the context of the energy sector, serving as a practical guide. The results, in fact, confirm the need for scientific and practical efforts to manage electricity production in an integrated perspective and provide a first glance at addressing the optimal design of energy source mix in the Italian regulation context, contributing to reducing the water footprint, without ignoring the economic aspects.
\end{abstract}

Keywords: electricity; water footprint; economic-water-energy nexus; Italy

\section{Introduction}

The challenge of sustainability was officially launched forty years ago, in 1987, thanks to the Report of the World Commission on environment and development: "our common future" [1]. The modern concept of sustainability was developed not only in the environmental dimension but on economic and social levels too [2]. Since 1987, many efforts have been made but there is still the need to complete the transition to sustainability with innovation processes, observation and analysing theories, policies and best practices [3]. One of the most important sectors called to manage this transformation is surely the energy sector [4], involving public policies [5] and company strategies where, for the latter, environmental technologies could also create competitive advantages [6,7]. Energy production has a remarkable negative impact on the natural environment, especially if the production comes from fossil fuels [4]. In addition, the exploitation of fossil fuels needs to be analysed considering all fuel cycles: intended as exploration, extraction, preparation, transformation, transportation, storage, etc. [8].

On the other hand, there are beneficial effects evaluating renewable sources, where all three of the above-mentioned dimensions of sustainability are positively influenced [9]. The renewable choice could also solve the problem of resource dependence of a few countries in the world [10], generally where oil and/or natural gas are located. Considering electricity, even if the positive effect of green electricity on local economy has already been highlighted and the possibility for consumers to make 
a different choice has been offered [9], currently, production still has a relevant share coming from fossil fuels, widely recognized as sources to be replaced [11]. Surely, the renewable option is a positive option but there is need for proper investigation before its adoption, specifically aiming at identifying pressure on the environment and avoiding possible imbalances $[12,13]$.

Evaluating the latest data available on world electricity production referring to 2015 provided by the International Energy Agency [14], renewable sources only account for $23.1 \%$ (hydro $16.0 \%$ and non-hydro renewables and waste $7.1 \%$ ) and $76.9 \%$ is dependent on fossil fuels, including nuclear power (oil 4.1\%; nuclear 10.6\%; natural gas $22.9 \%$; coal $39.3 \%$ ). It is not a great result if compared with data of more than 40 years ago. In 1973, in fact, of 6131 TWh total production, renewable sources made up $21.5 \%$ (hydro $20.9 \%$; non-hydro renewables and waste $0.6 \%$ ). Connected to this emergency, in recent years another urgency has come up, related to a strategic natural resource used in energy production. It is water scarcity, considered a key source in this point of view [15]. Freshwater scarcity opened an important debate in the field of sustainable water management [16-20]. Focusing on electricity, water use is used for all kinds of productions, above all for cooling in thermoelectricity [21-25].

Thanks to this very close relation, the term "water-energy nexus" was coined, with remarkable implications in the management of a real precious resource such as water [26,27]. Moreover, the situation has further worsened due to increasing periods and zones of arid weather [28]. This condition requires that, in a short time, the problem of water scarcity in electricity generation needs to be investigated, to find proper recommendations for companies and policy makers, focusing in particular on the impact of renewable and non-renewable sources.

In the following analysis Italy has been chosen as area of study for different reasons. Firstly, Italy reveals a minimum presence of fossil feedstock and a consequent relevant dependence on resources from abroad. Considering the last report of Unione Petrolifera [29], on 2016 national oil balance, the import of fossil fuels accounts for $92.6 \%$. Moreover, in 1999 there was the reform in electrical sector with the complete liberalization of electricity production, followed by important programs of incentives for renewable energy.

Evaluating the last 10-year period, the aim of this paper is to analyse the production of electricity, from an integrated economic and technical perspective, using the water footprint and economic water productivity approaches.

\section{Background}

\subsection{The Electric Energy Sector in Italy}

One of the most remarkable events in Italian electricity market could be the liberalization process started, as already mentioned, in 1999, thanks to a regulatory instrument, the Legislative Decree 16 March 1999, No. 79. From this "historical" moment, the electricity market gradually evolved in all stages of the supply-chain, from production to end consumers. Thanks to this change, production and sales became completely liberalized, while distribution was converted into locally licensed businesses. Moreover, related to the electricity transmission grid, there is substantially only one operator, Terna S.p.A., a company for which the Italian Ministry of Economy and Finance is the main shareholder. Distribution and transmission grids are natural monopolies and this is the reason for which their management has been concentrated in few operators.

To facilitate this global transformation, above all in the green perspective, important economic measures were provided for producers. Plants powered by renewable sources-with the exception of photovoltaic ones-were supported by the introduction of "Certificati Verdi" (from 1999 to 2015) and "Tariffa omnicomprensiva" (not yet expired since it will produce incentives until 2027), while photovoltaic installations received remarkable contributions from "Conto Energia" (available from 2003 to 2013). Currently, these measures have expired and been replaced by other policies, even if the latter do not have the same economic benefits of those above-mentioned. Definitely all measures adopted have had the goal to accelerate, concretely, the growth of green electricity in Italy, 
while promoting competition and efficiency among operators. Considering the last data available, referred to 2016, green electricity represents more than one third of the total gross production, even if there has been a decrease in the last two years [30].

Following the last report of the Italian Regulatory Authority for Electricity, Gas and Water, the total number of electricity producers is 13,311 (the total for thermoelectric is 398 , while for renewable it is 12,671 ) but, coming from a monopolistic context, there is a high concentration. The previous monopolistic company, Enel S.p.A., has a share of $22.1 \%$ and the first 12 companies manage almost one third of all electricity generated in Italy. Focusing on green electricity, all geothermal and almost all hydropower plants are managed by major companies, as shown in Table 1, while wind and photovoltaic generation are more fairly distributed [31]. Thanks to the aforementioned incentives, many little renewable plants were born, giving the possibility to household consumers, in the photovoltaic context, also to become producers, with small installations of a capacity from a minimum of $1 \mathrm{~kW}$ to 2 or $3 \mathrm{~kW}$.

Table 1. Contribution of the major groups to the renewable generation by source (percentage data).

\begin{tabular}{ccccc}
\hline Company & Hydropower & Geothermal & Wind & Solar \\
\hline Enel & 37.7 & 100.0 & 7.5 & 0.2 \\
A2A & 9.9 & 0.0 & 0.0 & 0.0 \\
Erg & 3.2 & 0.0 & 12.8 & 0.0 \\
Edison & 5.3 & 0.0 & 6.4 & 0.1 \\
CVA & 6.3 & 0.0 & 1.1 & 0.1 \\
Hydro Dolomiti Energia & 6.0 & 0.0 & 0.0 & 0.0 \\
Alperia & 4.6 & 0.0 & 0.0 & 0.0 \\
SEL & 4.2 & 0.0 & 0.0 & 0.0 \\
Iren & 2.9 & 0.0 & 0.0 & 0.1 \\
Ital Green Energy Holding & 0.0 & 0.0 & 0.0 & 0.2 \\
Falck Renewables & 0.0 & 0.0 & 3.9 & 0.2 \\
Acea & 0.9 & 0.0 & 0.0 & 0.1 \\
Api & 0.0 & 0.0 & 0.2 & 0.2 \\
Other & 19.9 & 0.1 & 68.4 & 99.2 \\
\hline Total & 100.0 & 100.0 & 100.0 & 100.0 \\
\hline
\end{tabular}

\subsection{The Water Footprint and Economic Water Productivity Approaches}

Quantitative indicators represent the most useful tools to assess complexity of managing freshwater system in a sustainable way, supporting policy and decision makers. Since the abundant number of indicators in the scientific literature have different intended use, end-users and geographic scale of application, it becomes difficult to identify suitable assessment methods. Notwithstanding, a lot of them are useful in evaluating scenarios and identifying trade-offs, rather than merely assessing and monitoring existing conditions [32].

In particular, the WF is an indicator of demand for water resources from both production and consumption perspectives [33,34]. The WF approach considers the place where water is consumed, the type of water used and when it is used. In fact, WF measures can be computed for given areas, regions or even for nations and can be divided into three different components: the blue fraction, which refers to the use of fresh surface water or groundwater; the green fraction, which indicates the use of water derived from precipitations on land that do not feed the runoff or recharge of groundwater, remaining temporarily on the surface of vegetation [35]; and finally the grey fraction, representing the volume of freshwater necessary to dilute pollutants to such a level that the ambient water quality remains above a given quality standard [36].

Concerning the time in which water is consumed, even if generally the WF refers to a year, it is possible to determine a WF time series, in order to assess how water pressures evolve over time [37]. 
Many scientific efforts have been made to face issues regarding sustainable water resource management, revealing the usefulness of WF in assessing production process factors which cannot be solely captured by monetary indicators [38].

In addition to, and in strict connection with, WF, the water productivity concept (WP) has no common definition [39] but generally refers to the ratio of the net benefits from a human production activity to the water quantity needed to produce those benefits. WP expressed in ton $/ \mathrm{m}^{3}$ is simply the inverse of the WF expressed in $\mathrm{m}^{3} / \mathrm{ton}$.

Since expressing WP in physical terms does not give insight about economic aspects related to water use, it is useful to compute economic water productivity (EWP) [19], defined as the value derived per unit of water used [40,41].

\section{Materials and Methods}

The water footprint of electricity, indicated by $\mathrm{WF}_{\mathrm{e}}$ and expressed in $\mathrm{m}^{3} \mathrm{TJ}_{\mathrm{e}}{ }^{-1}$, refers to the volume of water consumed and polluted at different stages of the production process.

In line with established scientific literature about the water footprint [42], the study distinguishes between three main stages of electricity production: fuel supply, construction and operation. The fuel supply stage is relevant only when electricity is produced using coal, oil, gas or other fuels. In the case of renewable energy sources only the construction and operation stages are considered.

The absolute water footprint of electricity $\left(\mathrm{WF}_{\mathrm{e}}\right)$, expressed as the total volume of water consumed during the production process per gross unit of electricity produced, depends mainly on the source of energy used.

For the aim of this study, fossil and renewable energy sources supporting Italian electricity production have been considered. In particular coal, conventional oil, natural gas, hydropower, photovoltaic, wind and geothermal were selected among energy sources whose data is needed for this research and have been previously observed and are annually available for the analysed period of time.

Because of the lack of data, not all energy sources that support Italian electricity production have been considered in this assessment. The study does not consider biomass sources, concentrated solar power, nuclear and pumping stations, which are a specific type of hydropower.

The period, analysed in this study, goes from 2007 up to 2016 because these years are the only ones when complete and reliable data for the variables used in our framework could be found.

In particular, the analysis is based on four fundamental variables: electricity production (E), water footprint of the fuel supply $\left(\mathrm{WF}_{\mathrm{e}, \mathrm{f}}\right)$; water footprint associated with the construction phase of power plants $\left(\mathrm{WF}_{\mathrm{e}, \mathrm{c}}\right)$, water footprint of the operational phase $\left(\mathrm{WF}_{\mathrm{e}, \mathrm{o}}\right)$ and the price of electricity $\left(\mathrm{P}_{\mathrm{e}}\right)$.

These variables could be considered as the most important dimensions affecting water sustainability in the electricity sector, since they enclose energy yield related to different sources, water pressure deriving from them and economic attributes.

Electricity production data (E) have been extracted from the statistical report on energy in Italy [30] and are measured by the gross production expressed in Gigawatt hours (GWh), as is shown in Table 2, subsequently converted into Terajoules $\left(\mathrm{TJ}_{\mathrm{e}}\right)$.

Table 2. Electricity production in Italy for the period 2007-2016 by energy sources (in GWh).

\begin{tabular}{ccccccccccc}
\hline & $\mathbf{2 0 0 7}$ & $\mathbf{2 0 0 8}$ & $\mathbf{2 0 0 9}$ & $\mathbf{2 0 1 0}$ & $\mathbf{2 0 1 1}$ & $\mathbf{2 0 1 2}$ & $\mathbf{2 0 1 3}$ & $\mathbf{2 0 1 4}$ & $\mathbf{2 0 1 5}$ & $\mathbf{2 0 1 6}$ \\
\hline Coal & 44,112 & 43,074 & 39,745 & 39,734 & 44,726 & 49,141 & 45,104 & 43,455 & 43,201 & 35,608 \\
Natural gas & 172,646 & 172,697 & 147,270 & 152,737 & 144,539 & 129,058 & 108,876 & 93,637 & 110,860 & 126,148 \\
Conventional oil & 22,865 & 19,195 & 15,878 & 9908 & 8474 & 7023 & 5418 & 4764 & 5620 & 4127 \\
\hline Fossil sources & 239,624 & 234,966 & 202,893 & 202,379 & 197,739 & 185,222 & 159,398 & 141,857 & 159,682 & 165,882 \\
\hline Hydropower & 32,815 & 41,623 & 49,138 & 51,117 & 45,823 & 41,875 & 52,773 & 58,545 & 45,537 & 42,432 \\
Geothermal & 5569 & 5520 & 5342 & 5376 & 5654 & 5592 & 5659 & 5916 & 6185 & 6289 \\
Wind & 4034 & 4861 & 6543 & 9126 & 9856 & 13,407 & 14,897 & 15,178 & 14,844 & 17,689 \\
Photovoltaic & 39 & 193 & 677 & 1906 & 10,796 & 18,862 & 21,589 & 22,306 & 22,942 & 22,104 \\
\hline Renewable sources & 42,458 & 52,198 & 61,699 & 67,524 & 72,129 & 79,735 & 94,918 & 101,946 & 89,508 & 88,513 \\
\hline & & & & Source: $[30]$. & & & & & &
\end{tabular}


The average data on water footprint $\left(\mathrm{WF}_{\mathrm{e}}\right)$ for the different stages of electricity production, reported in Table 3, have been extracted from Mekonnen et al. [42] and have been measured in Terajoules per gross unit of electricity produced $\left(\mathrm{m}^{3} / \mathrm{TJ} \mathrm{e}\right)$.

Table 3. The consumptive water footprint per unit of electricity per different stages of the production process by energy source.

\begin{tabular}{|c|c|c|c|c|}
\hline Energy Source & $\begin{array}{l}\text { Fuel Supply } W F_{e, f} \\
\qquad\left(m^{3} \mathrm{TJ}_{\left.\mathrm{e}^{-1}\right)}\right.\end{array}$ & $\begin{array}{c}\text { Construction } \\
\mathrm{WF}_{\mathrm{e}, \mathrm{c}}\left(\mathrm{m}^{3} \mathrm{TJ}_{\mathrm{e}}{ }^{-1}\right)\end{array}$ & $\begin{array}{l}\text { Operation } W_{F} F_{e, o} \\
\left(m^{3} \mathrm{TJ}_{\mathrm{e}}^{-1}\right)\end{array}$ & $\begin{array}{l}\text { Total } W F_{e} \\
\left(\mathrm{~m}^{3} \mathrm{TJ}_{\mathrm{e}}{ }^{-1}\right)\end{array}$ \\
\hline Coal & $17-665$ & $0.32-26$ & $61-1410$ & $79-2100$ \\
\hline Conventional oil & $20-546$ & $0.32-26$ & $194-615$ & 214-1190 \\
\hline Natural gas & $1.2-35$ & $0.32-1.1$ & $74-1200$ & $76-1240$ \\
\hline Hydropower & - & 0.30 & $300-850,000$ & $300-850,000$ \\
\hline Geothermal & - & 2.0 & $5.3-757$ & $7.3-759$ \\
\hline Wind & - & $0.10-9.5$ & $0.1-2.1$ & $0.2-12$ \\
\hline Photovoltaics & - & $5.3-221$ & $1.1-82$ & $6.4-303$ \\
\hline
\end{tabular}

Source: [41].

Price of electricity $\left(\mathrm{P}_{\mathrm{e}}\right)$ has been collected from the annual report on the status of services on the activity carried out by the Italian Authority for Electricity, Gas and Water System [31] and measured by the average annual gross final electricity prices for domestic and industrial consumers, expressed respectively in $€$ cents/kWh (Tables 4 and 5), subsequently converted in $€ / \mathrm{TJ}$.

The observed period substantially registers a continuous increase, except for few years, for all kind of consumers (household or industrial), independently from the consumption class [31].

Table 4. Gross final electricity prices for domestic consumers by consumption class ( $€$ cents $/ \mathrm{kWh})$.

\begin{tabular}{cccccc}
\hline & $<\mathbf{1 0 0 0} \mathbf{~ k W h}$ & $\mathbf{1 0 0 0 - 2 5 0 0 ~} \mathbf{k W h}$ & $\mathbf{2 5 0 0 - 5 0 0 0} \mathbf{k W h}$ & $\mathbf{5 0 0 0 - 1 5 , 0 0 0 ~} \mathbf{k W h}$ & $\mathbf{> 1 5 , 0 0 0} \mathbf{~ k W h}$ \\
\hline 2007 & 13.19 & 13.32 & 23.77 & 22.35 & 22.95 \\
2008 & 26.48 & 15.23 & 20.79 & 22.4 & 23.03 \\
2009 & 28.37 & 16.91 & 20.5 & 26.12 & 30.22 \\
2010 & 27.53 & 16.18 & 19.19 & 24.14 & 27.31 \\
2011 & 26.93 & 16.99 & 20.49 & 25.14 & 27.91 \\
2012 & 26.16 & 19.35 & 22.15 & 27.36 & 30.61 \\
2013 & 27.76 & 19.82 & 23.08 & 28.76 & 30.87 \\
2014 & 29.24 & 21.06 & 23.92 & 29.71 & 33.09 \\
2015 & 29.41 & 21.07 & 24.39 & 30.44 & 33.47 \\
2016 & 31.57 & 21.73 & 23.77 & 27.56 & 27.54 \\
\hline
\end{tabular}

Source: [31].

Table 5. Gross final electricity prices for industrial consumers by consumption class ( $€$ cents $/ \mathrm{MWh})$.

\begin{tabular}{|c|c|c|c|c|c|c|}
\hline & $\begin{array}{l}<20 \\
\text { MWh }\end{array}$ & $\begin{array}{l}\text { 20-500 } \\
\text { MWh }\end{array}$ & $\begin{array}{c}500-2000 \\
\text { MWh }\end{array}$ & $\begin{array}{c}2000-20,000 \\
\text { MWh }\end{array}$ & $\begin{array}{c}20,000-70,000 \\
\text { MWh }\end{array}$ & $\begin{array}{c}\text { 70,000-150,000 } \\
\text { MWh }\end{array}$ \\
\hline 2007 & 22.22 & 17.52 & 16.04 & 14.04 & 9.42 & 9.42 \\
\hline 2008 & 23.87 & 17.92 & 15.84 & 14.31 & 13.29 & 12.22 \\
\hline 2009 & 28.16 & 18.73 & 16.67 & 14.3 & 12.15 & 10.07 \\
\hline 2010 & 29.71 & 17.54 & 16.03 & 14.03 & 12.37 & 11.16 \\
\hline 2011 & 31.43 & 21.21 & 18.33 & 15.15 & 14.06 & 11.49 \\
\hline 2012 & 29.08 & 23.31 & 21.24 & 21.97 & 15.1 & 12.77 \\
\hline 2013 & 32.17 & 23.31 & 19.73 & 17.56 & 14.76 & 12.54 \\
\hline 2014 & 31.41 & 23.7 & 20.17 & 17.55 & 15.38 & 11.95 \\
\hline 2015 & 32.24 & 22.47 & 18.64 & 16.62 & 13.84 & 11.38 \\
\hline 2016 & 32.27 & 21.54 & 17.89 & 15.92 & 13.58 & 10.03 \\
\hline
\end{tabular}

Source: [31]. 
For each energy source used to support Italian electricity production during the period 2007-2016, the present study calculates the consumptive water footprint in electricity production $\left(\mathrm{WF}_{\mathrm{e}, \text { total }}\right.$, $\mathrm{m}^{3}$ per year) as follows:

$$
\mathrm{WF}_{\mathrm{e}, \text { total }}=\left(\mathrm{WF}_{\mathrm{e}, \mathrm{f}}+\mathrm{WF}_{\mathrm{e}, \mathrm{c}}+\mathrm{WF}_{\mathrm{e}, \mathrm{o}}\right) \times \mathrm{E}
$$

where:

$\mathrm{WF}_{\mathrm{e}, \mathrm{f}}$ is the average water footprint of the fuel supply per unit of electricity $\left(\mathrm{m}^{3} \mathrm{TJ}_{\mathrm{e}}{ }^{-1}\right)$;

$\mathrm{WF}_{\mathrm{e}, \mathrm{c}}$ is the average water footprint associated with the construction phase of the power plant expressed in units of electricity produced for the entire duration of the plant $\left(\mathrm{m}^{3} \mathrm{TJ}_{\mathrm{e}}{ }^{-1}\right)$;

$\mathrm{WF}_{\mathrm{e}, \mathrm{o}}$ is the average water footprint in the operational phase per unit of electricity produced by fossil or renewable energy source $\left(\mathrm{m}^{3} \mathrm{TJ}_{\mathrm{e}}^{-1}\right)$;

$\mathrm{E}$ is the annual production of electricity from fossil or renewable energy sources ( $\mathrm{T} \mathrm{J}_{\mathrm{e}}$ per year).

After comparing the percentage of contribution of fossil and renewable sources to the production of the electricity sector, the study then compares the percentage of contribution of fossil and renewable sources to the consumptive water footprint of Italian electricity production for each year analysed.

Furthermore, distinguishing between renewable and fossil sources, the paper proceeds to assess the total consumptive water footprint $\left(\mathrm{WF}_{\mathrm{e}, \text { total }}\right)$ generated by each energy source for the electricity production (E) in Italy during the period 2007-2016.

Finally, the paper, following the methodology of Owusu-Sekyere et al. [43], computes the time trend of economic water productivity of electricity $\left(\mathrm{EWP}_{\mathrm{e}}\right)$, based on prices $\left(\mathrm{P}_{\mathrm{e}}\right)$ distinguished per domestic and industrial consumption class and consumptive water footprint per unit of electricity $\left(\mathrm{WF}_{\mathrm{e}}\right)$, measured in $€ / \mathrm{m}^{3}$ and expressed by equation:

$$
\mathrm{EWP}_{\mathrm{e}}=\frac{\mathrm{P}_{\mathrm{e}}}{\mathrm{WF}_{\mathrm{e}}}
$$

where:

$\mathrm{P}_{\mathrm{e}}$ represents the gross final electricity prices for domestic or industrial consumers by consumption class in $€ / T \mathrm{~T}$;

$\mathrm{WF}_{\mathrm{e}}$ is the average total water footprint per unit of electricity produced by fossil or renewable energy source $\left(\mathrm{m}^{3} \mathrm{TJ}_{\mathrm{e}}^{-1}\right)$.

\section{Results and Discussion}

Figure $1 \mathrm{~b}$ highlights that the major contribution to the consumptive water footprint of electricity production in Italy is due to renewable sources, even if, on the contrary, from a production perspective fossil fuels represent the main energy sources (Figure 1a). As shown by the time trend in Figure 1b, fossil fuels contribute on average for less than the $4.4 \%$ of the total water footprint consumption in the period 2007-2016, registering a negative peak in 2014.

From these results, it seems that fossil sources are more sustainable in a water perspective than renewable ones and could be used as an effective energy source, relaxing pressure on water resources. Nevertheless, this evidence is mainly due to the contribution of hydropower in terms of water footprint. It has been debated whether hydroelectric generation is merely an in-stream water user or whether it consumes water too.

As demonstrated by Mekonnen and Hoekstra [44] hydroelectric generation represents a significant water consumption, even if great differences exist in relation to the local climate and flooded area of the power plant (Table 3). 


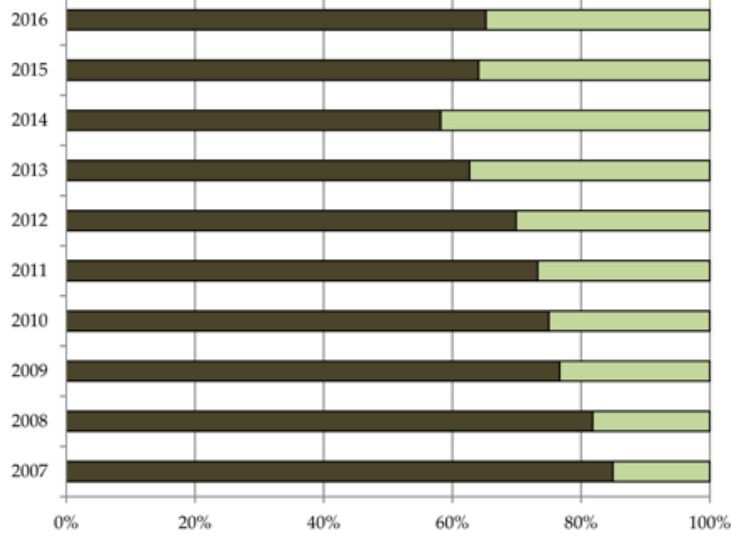

a)

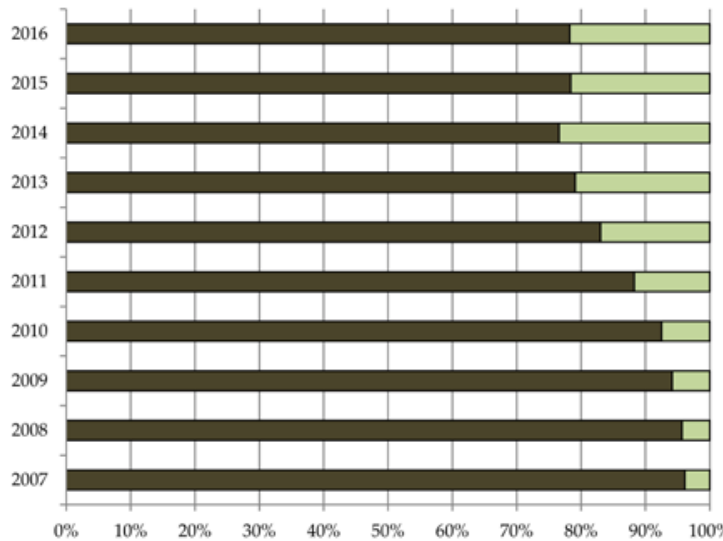

c)
QElectricity from fossil sources

口Electricity from renewable

sources

Electricity from fossil sources

Electricty from renewable sources
2016

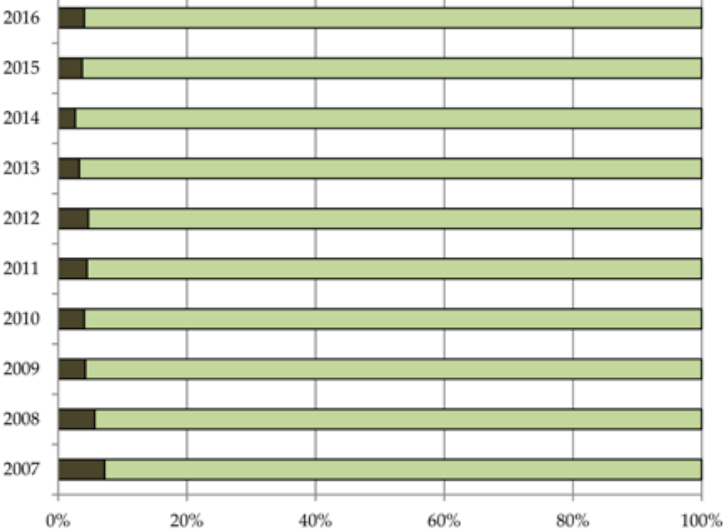

b)

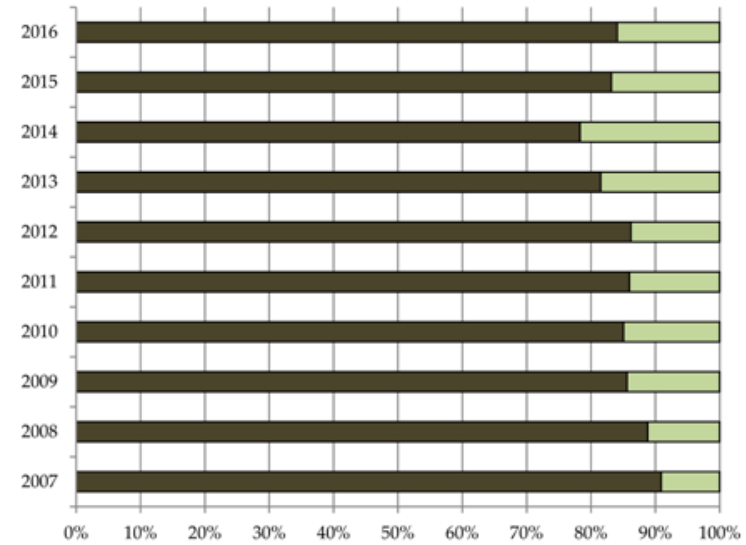

d)
-WF of electricity from fossil

source

aWF of electricity from

renewable sources

WF of electricity from fossil

QWF of electricity from
renewable sources

Figure 1. (a) Percentage of electricity production in Italy per energy source over the period 2007-2016; (b) Percentage of consumptive water footprint of electricity production in Italy per energy source over the period 2007-2016; (c) Percentage of electricity production in Italy per energy source over the period 2007-2016 (excluding hydropower from renewable sources); (d) Percentage of consumptive water footprint of electricity production in Italy per energy source over the period 2007-2016 (excluding hydropower from renewable sources). 
Excluding hydropower from the analysis for the above-mentioned reason, the percentage of fossil sources over the consumptive water footprint of electricity production in Italy in the period 2007-2016 significantly increased, overturning previous results.

As highlighted by the time trend in Figure 1d, fossil fuels contribute on average for almost $85 \%$ of the total water footprint consumption in the period 2007-2016, registering a negative peak in 2014. These results are in line with the contribution of fossil and renewable sources to the Italian electricity mix from a production perspective over the period 2007-2016 (Figure 1c) and demonstrate a competitive advantage of wind, photovoltaics and geothermal in terms of water sustainability. In fact, these renewable sources ensure better performances, i.e., lower values of average water footprint per unit of electricity produced, compared to fossil ones.

Furthermore, Figure 2, illustrating the total consumptive water footprint generated by each fossil source for the electricity production in Italy during the period 2007-2016, highlights a negative trend, so a lower water footprint caused by the use of non-renewable sources, supported by the minimal contribution of conventional oil. The latter, far from being considered the best energy source alternative, can still contribute to a slack in water pressures, compared to the other two fossil sources.

Figure 3 illustrates the time trend of each renewable energy source, excluding hydropower. Results confirm that, renewable sources which provide the use of water in their life cycle (i.e., geothermal source), predominantly affect the total consumptive water footprint of electricity production in Italy, while ensuring lower levels of electricity production than the other renewable sources. Although in the last years wind source has grown ensuring a substantial increase in the Italian electricity production, it contributes less than the other renewable sources to the consumptive water footprint, highlighting a clear water comparative advantage.

Turning the attention to economic water productivity results (Table 6), it is possible to notice that the highest average value of parameter EWP of a unit of electricity derived from fossil sources is associated with the domestic consumption class $>15,000 \mathrm{kWh}\left(104.62 € / \mathrm{m}^{3}\right)$, followed by the domestic consumption class $<1000 \mathrm{kWh}\left(97.28 € / \mathrm{m}^{3}\right)$.

These results are confirmed also analysing the EWP of a unit of electricity derived from all renewable sources. In this case, absolute average values of EWP are widely different than those derived from fossil sources, however maximum average values correspond to the first and last domestic consumption class, respectively 1.88 and $1.75 € / \mathrm{m}^{3}$.

If hydropower is excluded, values of EWP for a unit of electricity from renewable sources are similar to those calculated considering fossil sources, registering on average almost $-10 \%$ for each domestic consumption class.

Table 7 shows results of economic water productivity per unit of electricity in Italy per industrial consumption class. Differently from the domestic consumption class, industrial ones highlight a trend in EWP inversely proportional to the consumption class increase.

Considering electricity derived from fossil sources, from renewable sources and from renewable sources excluding hydropower, EWP average values vary from respectively $106.71,1.92$ and $96.95 € / \mathrm{m}^{3}$ for the industrial consumption class $<20 \mathrm{MWh}$, to $41.25,0.73$ and $36.46 € / \mathrm{m}^{3}$ for the maximum industrial consumption class (70,000-150,000 MWh).

Focusing on time trends (Figure 4), the EWP values related to the three types of electricity supply highlight growth. Notwithstanding this increasing trend varies relevantly depending on electricity sources. It is more accentuated for the EWP of electricity from renewable sources without considering hydropower. Even distinguishing domestic and industrial electricity consumption, time series assume the same functional form registering shifts in the absolute annual values. 


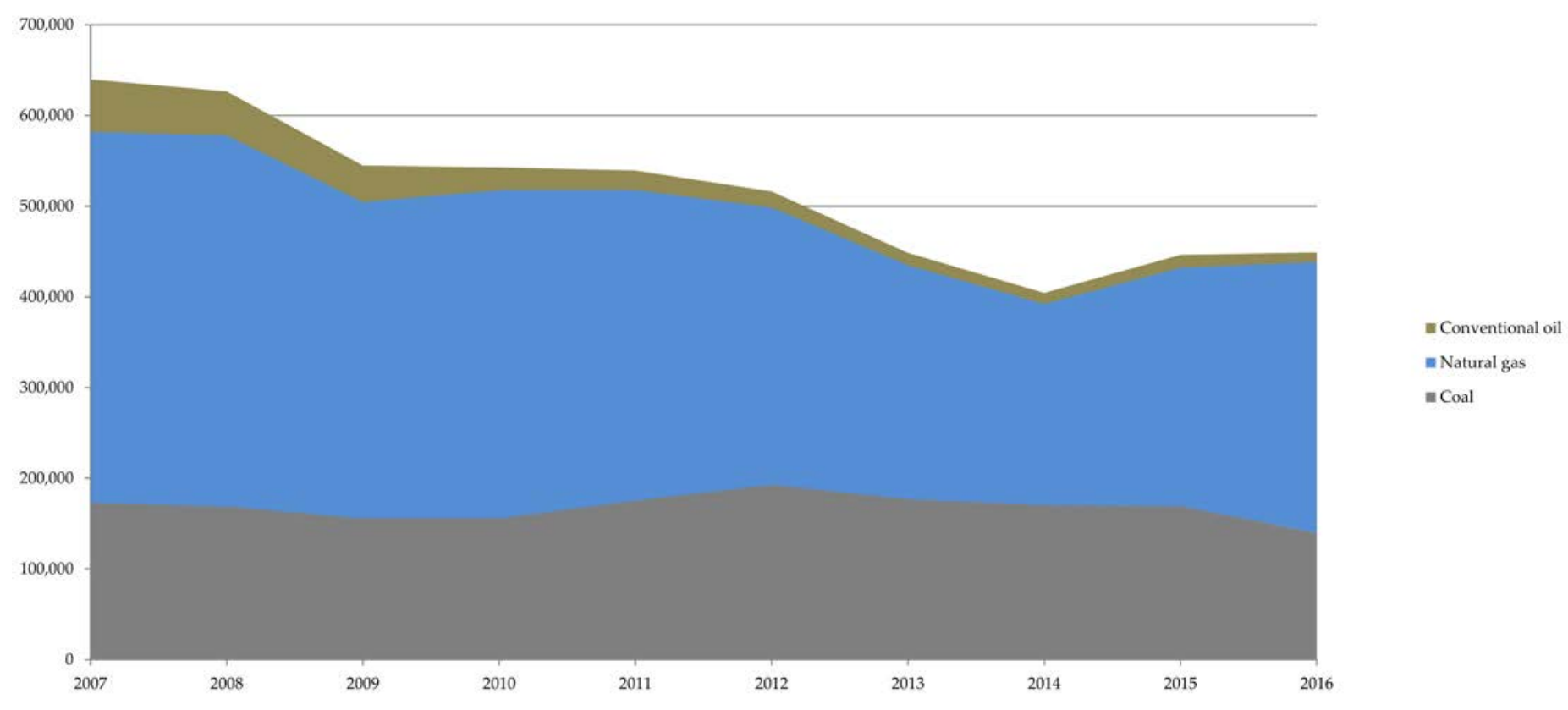

Figure 2. Total consumptive water footprint of electricity production in Italy $\left(\mathrm{WF}_{\text {ettal }}\right)$, expressed in thousands of $\mathrm{m}^{3}$, per each fossil source over the period $2007-2016$. 


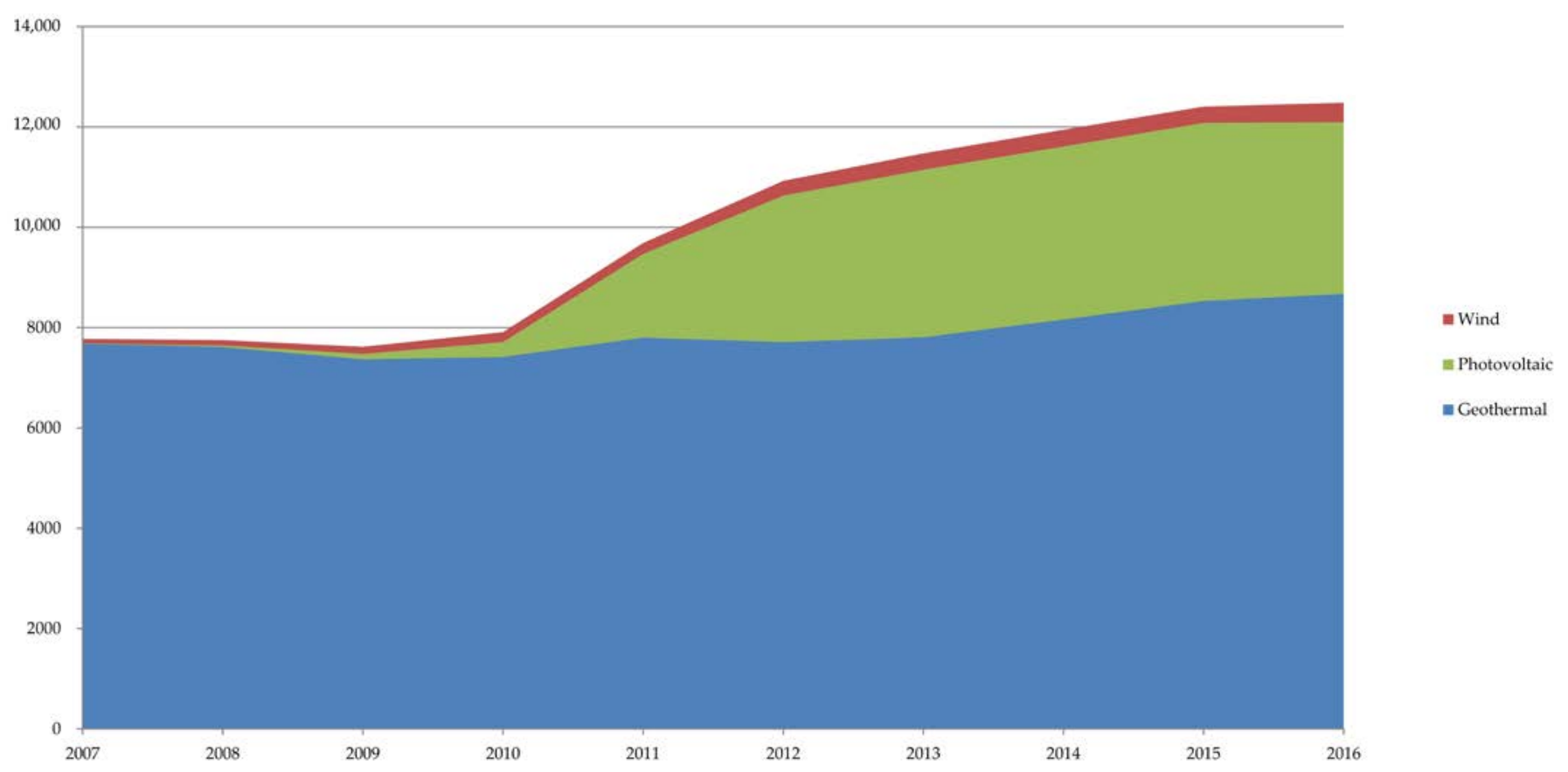

Figure 3. Total consumptive water footprint of electricity production in Italy $\left(\mathrm{WF}_{\mathrm{e}, \text { total }}\right)$, expressed in thousands of $\mathrm{m}^{3}$, per each renewable source over the period 2007-2016 (excluding hydropower).

Table 6. Descriptive statistics of economic water productivity $\left(\mathrm{EWP}_{\mathrm{e}}\right.$ ) for a unit of electricity in Italy over the period 2007-2016 (in $\left.€ / \mathrm{m}^{3}\right)$ per domestic consumption class.

\begin{tabular}{|c|c|c|c|c|c|c|c|c|c|c|c|c|c|c|c|}
\hline \multirow[b]{2}{*}{ Mean } & \multicolumn{3}{|c|}{$<1000 \mathrm{kWh}$} & \multicolumn{3}{|c|}{$1000-2500 \mathrm{kWh}$} & \multicolumn{3}{|c|}{$2500-5000 \mathrm{kWh}$} & \multicolumn{3}{|c|}{$5000-15,000 \mathrm{kWh}$} & \multicolumn{3}{|c|}{$>15,000 \mathrm{kWh}$} \\
\hline & 97.28 & 1.75 & 88.48 & 66.21 & 1.20 & 61.52 & 81.06 & 1.45 & 72.36 & 96.26 & 1.73 & 87.36 & 104.62 & 1.88 & 94.61 \\
\hline Dev. Std. & 17.88 & 0.56 & 51.49 & 9.31 & 0.41 & 37.34 & 5.93 & 0.37 & 39.57 & 8.55 & 0.50 & 49.28 & 11.45 & 0.53 & 52.58 \\
\hline Min & 49.40 & 0.68 & 19.91 & 49.89 & 0.69 & 20.10 & 71.56 & 1.01 & 27.86 & 83.71 & 1.12 & 30.01 & 85.96 & 1.15 & 30.86 \\
\hline Max & 116.66 & 2.63 & 171.08 & 80.30 & 1.81 & 117.76 & 89.03 & 1.98 & 128.81 & 108.92 & 2.39 & 149.35 & 119.76 & 2.63 & 163.03 \\
\hline
\end{tabular}

For each domestic consumption class, the three columns represent in order EWP of a unit of electricity derived from fossil sources, from renewable sources and from renewable sources excluding hydropower. 
Table 7. Descriptive statistics of economic water productivity $\left(E W P_{e}\right)$ for a unit of electricity in Italy over de period $2007-2016$ (in $€ / \mathrm{m}^{3}$ ) per industrial consumption class.

\begin{tabular}{ccccccccccccccccccc}
\hline & \multicolumn{1}{c}{$<\mathbf{M W h}$} & \multicolumn{3}{c}{$\mathbf{2 0 - 5 0 0} \mathbf{M W h}$} & \multicolumn{3}{c}{$\mathbf{5 0 0 - 2 0 0 0} \mathbf{~} \mathbf{W h}$} & \multicolumn{2}{c}{$\mathbf{2 0 0 0 - 2 0 , 0 0 0} \mathbf{M W h}$} & \multicolumn{2}{c}{$\mathbf{2 0 , 0 0 0 - 7 0 , 0 0 0} \mathbf{M W h}$} & $\mathbf{7 0 , 0 0 0 -} \mathbf{1 5 0 , 0 0 0} \mathbf{M W h}$ \\
\hline Mean & 106.71 & 1.92 & 96.95 & 75.54 & 1.37 & 69.12 & 65.85 & 1.18 & 59.57 & 58.85 & 1.06 & 53.81 & 48.84 & 0.88 & 44.30 & 41.25 & 0.73 & 36.46 \\
Dev. Std. & 11.78 & 0.56 & 54.47 & 7.65 & 0.41 & 39.28 & 5.56 & 0.33 & 32.93 & 7.96 & 0.34 & 31.53 & 5.60 & 0.25 & 24.58 & 3.68 & 0.18 & 18.92 \\
Min & 83.23 & 1.15 & 31.98 & 65.41 & 0.90 & 24.01 & 59.40 & 0.79 & 21.22 & 52.32 & 0.72 & 19.17 & 35.28 & 0.49 & 14.22 & 35.28 & 0.49 & 13.80 \\
Max & 119.25 & 2.69 & 174.88 & 83.64 & 1.79 & 116.73 & 76.21 & 1.62 & 97.44 & 78.83 & 1.67 & 100.79 & 54.18 & 1.15 & 73.59 & 45.83 & 0.97 & 58.58 \\
\hline
\end{tabular}

For each industrial consumption class, the three columns represent in order EWP of a unit of electricity derived from fossil sources, from renewable sources and from renewable sources excluding hydropower.

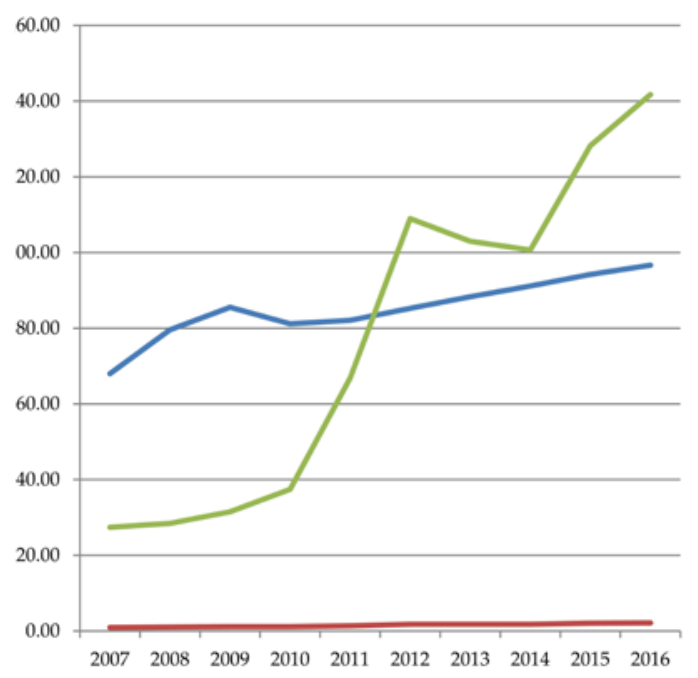

a) $\begin{array}{llllllllll}2007 & 2008 & 2009 & 2010 & 2011 & 2012 & 2013 & 2014 & 2015 & 2016\end{array}$

EWP of electricity from fossi

$$
\text { sources }
$$

$$
\text { sources }
$$

EWP of electricity from renewable sources excluding hydropower

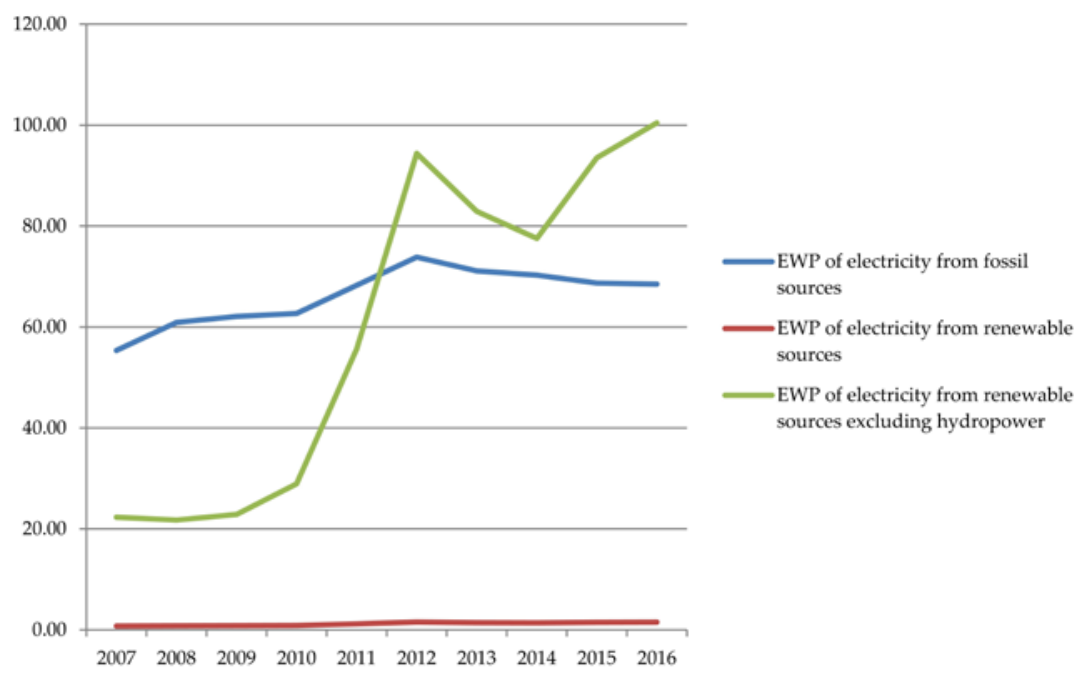

b)

Figure 4. Time trend of average economic water productivity for electricity domestic (a) and industrial (b) consumptions in Italy over the period 2007-2016 per energy sources (in $€ / \mathrm{m}^{3}$ ). 


\section{Conclusions}

The analysis carried out in this work shows a more integrated perspective to evaluating the impact of electricity production above all when, excluding the primary sources, other important natural resources are used in the generation processes. It is the case of freshwater, where its scarcity has opened an important comparison. Electricity generation, considering the operation management, is called to a deep reflection. In a detailed framework, this study provides a water footprint analysis not only from the physical point of view but it also considers the water utilization from an economic perspective [19], aiming at a complete vision in the modern concept of sustainable development. Adding economic water productivities, i.e., the monetary value of every cubic meter of water used in producing electricity, undoubtedly represents a step-forward in water research development and sustainability policies. The EWP, relating the yield values per unit water use with the water prices, appears adequate to assess the effectiveness of energy policies, measuring the economic value generated by water, as influenced by prices.

This enlarged vision highlights an important aspect to be evaluated in the water efficiency direction, that is, not all electricity generation coming from renewable sources has the same impact. Renewable options need to be carefully investigated from a freshwater consumption approach. A first estimation, considering the features of the environmental and economic context where electricity generation has to be settled, is needed. There is vast scientific literature that declares the benefits of renewable energy sources but there is a lack of specific research that specifically assesses their impact on local community through the three-dimensional sustainability approach [45].

Therefore, the obtained results could be useful in particular cases for moving attention from hydropower towards other renewables, as photovoltaic or wind, above all when the hydropower solution could create some imbalances. For example, if a hydropower plant is located in an area where evaporation is at higher, it implies a water efficiency loss, which could be recovered through alternative source management.

Economic aspects related to water consumption, in terms of price paid for the natural resource use, represents another interesting element rising from the results of this study. This evidence comes from the consumption class analysis. Being a household or industrial electricity user positioned in the lower consumption classes does not imply a lower contribution in terms of price paid for freshwater resource. This aspect could surely be revised to ensure a better redistribution of the economic water productivity, favouring a more conscious use. This additional information should be considered as a valid instrument to better qualify the entire energy value proposition. In this way energy producers could increase their competitive advantages creating a stronger relationship with customers and stakeholders also in a sustainable marketing perspective [46]. Previous studies, applied in other world regions, showed, in fact, how customers are favourable to renewable energy sources and also are willing to pay an additional amount for them [47]. Finally, taking into consideration all the observed elements, this study could represent an original contribution for a more appropriate natural resource management in electricity production, aiming at a more sustainable exploitation of freshwater.

The assessment of economic-water-energy nexus related to electricity production, aside from representing a novelty in the scientific studies, could be replicated using other applicability scales.

Further research should be addressed towards an integration of other footprint indicators in the sustainability assessment of electricity production.

Author Contributions: The following authors contributed in full to this work. Domenico Morrone analysed the sources and the literature and contributed to the data collection. Pier Paolo Miglietta contributed to the research design and methodology. Federica De Leo carried out a detailed revision. All the authors wrote the body of the paper, read and approved the final manuscript.

Conflicts of Interest: The authors declare no conflict of interest. 


\section{References}

1. World Commission on Environment and development [WCED]. Our Common Future; Oxford University Press: Oxford, UK, 1987; ISBN 978-0-1928-2080-8.

2. Elkington, J. Cannibals with Forks. The Triple Bottom Line of 21st Century Business; John Wiley \& Sons: Hoboken, NJ, USA, 1997; ISBN 978-1-8411-2084-3.

3. Elzen, B.; Geels, F.W.; Green, K. System Innovation and the Transition to Sustainability: Theory, Evidence and Policy; Edward Elgar Publishing: Cheltenham, UK, 2004; ISBN 978-1-84376-683-4.

4. Dincer, I. Environmental impacts of energy. Energy Policy 1999, 27, 845-854. [CrossRef]

5. Kern, F.; Smith, A. Restructuring energy systems for sustainability? Energy transition policy in the Netherlands. Energy Policy 2008, 36, 4093-4103. [CrossRef]

6. Porter, M.E.; Van der Linde, C. Green and competitive: Ending the stalemate. Harv. Bus. Rev. 1995, 73, 120-134.

7. Shrivastava, P. Environmental technologies and competitive advantage. Strateg. Manag. J. 1995, 16, $183-200$. [CrossRef]

8. Omer, A. Energy, environment, and sustainable development in Sudan. IIOAB J. 2011, 2, 31-44.

9. Akella, A.K.; Saini, R.P.; Sharma, M.P. Social, economical and environmental impacts of renewable energy systems. Renew. Energy 2009, 34, 390-396. [CrossRef]

10. Bull, S.R. Renewable energy today and tomorrow. Proc. IEEE 2001, 89, 1216-1226. [CrossRef]

11. Lund, H. Renewable energy strategies for sustainable development. Energy 2007, 32, 912-919. [CrossRef]

12. Miglietta, P.P.; De Leo, F.; Toma, P. L'impronta ecologica delle energie rinnovabili in Italia. In Proceedings of the $\mathrm{XXVI}^{\circ}$ Congresso Nazionale di Scienze Merceologiche Innovazione, Sostenibilità e Tutela dei Consumatori: L'Evoluzione delle Scienze Merceologiche per la Creazione di Valore e Competitività, Pisa, Italy, 13-15 February 2014. [CrossRef]

13. Mekhilef, S.; Siga, S.; Saidur, R. A review on palm oil biodiesel as a source of renewable fuel. Renew. Sustain. Energy Rev. 2011, 15, 1937-1949. [CrossRef]

14. International Energy Agency. Key World Energy Statistics. Available online: https://www.iea.org/ publications / freepublications/publication/KeyWorld2017.pdf (accessed on 9 December 2017).

15. Carrillo, A.M.R.; Frei, C. Water: A key resource in energy production. Energy Policy 2009, 37, 4303-4312. [CrossRef]

16. Gleick, P.H. Water in crisis: Paths to sustainable water use. Ecol. Appl. 1998, 8, 571-579. [CrossRef]

17. Postel, S.L. Entering an era of water scarcity: The challenges ahead. Ecol. Appl. 2000, 10, 941-948. [CrossRef]

18. Loucks, D.P. Sustainable water resources management. Water Int. 2000, 25, 3-10. [CrossRef]

19. Pereira, S.L.; Cordery, I.; Iacovides, I. Conceptual thinking in coping with water scarcity. In Coping with Water Scarcity: Addressing the Challenges; Pereira, S.L., Cordery, I., Iacovides, I., Eds.; Springer: Berlin, Germany, 2009; pp. 77-98, ISBN 978-1-4020-9579-5.

20. Haasnoot, M.; Middelkoop, H.; Van Beek, E.; Van Deursen, W.P.A. A method to develop sustainable water management strategies for an uncertain future. Sustain. Dev. 2011, 19, 369-381. [CrossRef]

21. Inhaber, H. Water use in renewable and conventional electricity production. Energy Sources 2004, 26, 309-322. [CrossRef]

22. Kenny, J.F.; Barber, N.L.; Hutson, S.S.; Linsey, K.S.; Lovelace, J.K.; Maupin, M.A. Estimated Use of Water in the United States in 2005; US Geological Survey: Reston, WV, USA, 2009; ISBN 978-1-4113-2600-2.

23. Meldrum, J.; Nettles-Anderson, S.; Heath, G.; Macknick, J. Life cycle water use for electricity generation: A review and harmonization of literature estimates. Environ. Res. Lett. 2013, 8, 1-18. [CrossRef]

24. Averyt, K.; Macknick, J.; Rogers, J.; Madden, N.; Fisher, J.; Meldrum, J.; Newmark, R. Water use for electricity in the United States: An analysis of reported and calculated water use information for 2008. Environ. Res. Lett. 2013, 8, 1-9. [CrossRef]

25. Byers, E.A.; Hall, J.W.; Amezaga, J.M. Electricity generation and cooling water use: UK pathways to 2050. Glob. Environ. Chang. 2014, 25, 16-30. [CrossRef]

26. Kenney, D.S.; Wilkinson, R. The Water-Energy Nexus in the American West; Edward Elgar Publishing: Cheltenham, UK, 2011; ISBN 978-1-8498-0936-8.

27. Schnoor, J.L. Water-energy nexus. Environ. Sci. Technol. 2011, 45, 5065. [CrossRef] [PubMed] 
28. Fthenakis, V.; Kim, H.C. Life-cycle uses of water in US electricity generation. Renew. Sustain. Enery Rev. 2010, 14, 2039-2048. [CrossRef]

29. Unione Petrolifera. Annual Report 2017. Available online: http:/ /www.unionepetrolifera.it/?page_id=6419 (accessed on 9 December 2017).

30. Terna. Dati Statistici Sull'energia Elettrica in Italia. Available online: https://www.terna.it/it-it/ sistemaelettrico/statisticheeprevisioni/datistatistici.aspx (accessed on 9 December 2017).

31. Autorità per L'energia Elettrica e il gas (AEEGSI). Relazioni Annuali Sullo Stato Dei Servizi e Sull'attività Svolta. Presidenza del Consiglio dei Ministri, Dipartimento per L'informazione e L'editoria. Available online: https:/ / www.autorita.energia.it/it/relaz_ann/17/17.htm (accessed on 9 December 2017).

32. Vollmer, D.; Regan, H.M.; Andelman, S.J. Assessing the sustainability of freshwater systems: A critical review of composite indicators. Ambio 2016, 45, 765-780. [CrossRef] [PubMed]

33. Hoekstra, A.Y.; Chapagain, A.K.; Aldaya, M.M.; Mekonnen, M.M. The Water Footprint Assessment Manual: Setting the Global Standard; Earthscan: London, UK, 2011.

34. Hoekstra, A.Y.; Chapagain, A.K. Globalization of Water: Sharing the Planet's Freshwater Resources; Wiley-Blackwell: Oxford, UK, 2008.

35. Falkenmark, M.; Rockström, J. The new blue and green water paradigm: Breaking new ground for water resources planning and management. J. Water Resour. Plan. Manag. 2006, 132, 129-132. [CrossRef]

36. Miglietta, P.P.; Toma, P.; Fanizzi, F.P.; De Donno, A.; Coluccia, B.; Migoni, D.; Bagordo, F.; Serio, F. A Grey Water Footprint Assessment of Groundwater Chemical Pollution: Case Study in Salento (Southern Italy). Sustainability 2017, 9, 799. [CrossRef]

37. Roson, R.; Sartori, M.A. Decomposition and comparison analysis of international water footprint time series. Sustainability 2015, 7, 5304-5320. [CrossRef]

38. Antonelli, M.; Sartori, M. Unfolding the potential of the Virtual Water concept. What is still under debate? Environ. Sci. Policy 2015, 50, 240-251. [CrossRef]

39. Rodrigues, G.C.; Pereira, L.S. Assessing economic impacts of deficit irrigation as related to water productivity and water costs. Biosyst. Eng. 2009, 103, 536-551. [CrossRef]

40. Garrido, A.; Llamas, R.; Varela-Ortega, C.; Novo, P.; Rodríguez-Casado, R.; Aldaya, M.M. Water Footprint and Virtual Water Trade in Spain: Policy Implications; Springer: New York, NY, USA, 2010; ISBN 978-1-4419-5741-2.

41. Chouchane, H.; Hoekstra, A.Y.; Krol, M.S.; Mekonnen, M.M. The water footprint of Tunisia from an economic perspective. Ecol. Indic. 2015, 52, 311-319. [CrossRef]

42. Mekonnen, M.M.; Gerbens-Leenes, P.W.; Hoekstra, A.Y. The consumptive water footprint of electricity and heat: A global assessment. Environ. Sci. Water Res. Technol. 2015, 1, 285-297. [CrossRef]

43. Owusu-Sekyere, E.; Scheepers, M.E.; Jordaan, H. Economic Water Productivities along the Dairy Value Chain in South Africa: Implications for Sustainable and Economically Efficient Water-use Policies in the Dairy Industry. Ecol. Econ. 2017, 134, 22-28. [CrossRef]

44. Mekonnen, M.M.; Hoekstra, A.Y. The blue water footprint of electricity from hydropower. Hydrol. Earth Syst. Sci. 2012, 16, 179-187. [CrossRef]

45. Del Río, P.; Burguillo, M. Assessing the impact of renewable energy deployment on local sustainability: Towards a theoretical framework. Renew. Sustain. Energy Rev. 2008, 12, 1325-1344. [CrossRef]

46. Morrone, D. The influence of sustainable development on marketing theory. Megatrend Rev. 2012, 9, 1-19.

47. Farhar, B.C. Willingness to pay for electricity from renewable resources: A review of utility market research. Natl. Renew. Energy Lab. 1999, 550, 1-20.

(C) 2018 by the authors. Licensee MDPI, Basel, Switzerland. This article is an open access article distributed under the terms and conditions of the Creative Commons Attribution (CC BY) license (http://creativecommons.org/licenses/by/4.0/). 